\title{
THE APPLICATION OF DP POLAROGRAPHY FOR THE DETERMINATION OF ZINC AND CONTENT OF ZINC PYRITHIONE IN ANTI-DANDRUFF SHAMPOOS
}

\author{
UDC $546.47: 543.552$
}

\author{
Slavica M. Blagojević ${ }^{1 *}$, Ferenc T. Pastor ${ }^{2}$, Ivan R. Borić ${ }^{1}$, \\ Nataša M. Erić ${ }^{1}$, Desanka Ž. Sužnjević ${ }^{3}$ \\ ${ }^{1}$ University of Belgrade, Faculty of Pharmacy, Department of Physical Chemistry and \\ Instrumental Methods, Belgrade, Serbia \\ ${ }^{2}$ University of Belgrade, Faculty of Chemistry, Department of Analytical Chemistry, \\ Belgrade, Serbia \\ ${ }^{3}$ Institute of General and Physical Chemistry, Belgrade, Serbia
}

\begin{abstract}
Commercially formulated anti-dandruff shampoos contain zinc pyrithione $(Z P T)$ as an active ingredient that has antifungal, antibacterial and anti-seborrheic properties. The determination of ZPT concentration in commercial anti-dandruff shampoos by differential pulse polarography (DPP) was based on the electrochemical reduction of zinc ions in ammoniacal buffer $\mathrm{pH}$ 10.2, and the linear dependence of the reduction differential pulse peak current at the potential $-1.33 \mathrm{~V} v$ s. concentration of zinc. Using the calibration curve method, it was found that the range of linearity for the determination of zinc concentration was from $1.28 \times 10^{-5}$ to $1.39 \times 10^{-4} \mathrm{~mol} \mathrm{~L}^{-1}$ (linear regression equation: $I=-0.097+6.635 \times 10^{5} \mathrm{c}$ ). Surface active ingredients and micro-components in the shampoos did not exert a polarographic interference for the determination of zinc and did not affect the indirect determination of the content of the active ingredient ZPT. The concentrations of zinc in the analyzed anti-dandruff shampoo samples were determined by the standard addition method, resulting in 4.20 $\times 10^{-2} \mathrm{~mol} \mathrm{~L} L^{-1}, 1.76 \times 10^{-1} \mathrm{~mol} \mathrm{L^{-1 }}$ and $1.82 \times 10^{-1} \mathrm{~mol} \mathrm{~L} L^{-1}$. The results of DPP determinations of zinc and ZPT show that the content of ZPT was $0.28 \%, 1.15 \%$ i.e. $1.19 \%$ and was below the maximum recommended level of ZPT in anti-dandruff shampoos. This simple and sensitive differential pulse polarography method is suitable for a routine and rapid control of the active ingredient content, as well as for the quality control of anti-dandruff shampoos.
\end{abstract}

Key words: Zinc pyrithione, anti-dandruff shampoo, differential pulse polarography

Received July $8^{\text {th }}, 2015$; accepted December $14^{\text {th }}, 2015$.

The present investigations were supported by the Ministry of Education, Science and Technological Development of the Republic of Serbia, Grant $N^{\circ} 172015$.

*Contacts of the corresponding author. E-mail: slavicab@pharmacy.bg.ac.rs 


\section{INTRODUCTION}

Commercially formulated shampoos contain surfactants (primary and additional), micro-components (color, perfume, preservative and sodium chloride) and an active ingredient that determines the intent of the shampoo. The mixture sodium lauryl ether sulfates (SLES) of different chain lengths (mixture of $\mathrm{C}_{12}-\mathrm{C}_{13}$ SLES and $\mathrm{C}_{12}-\mathrm{C}_{14}$ SLES; composition depends on the type of vegetable oil from which surfactant was obtained), is commonly used primary anionic surfactant. Additional amphoteric surfactant in the formulation is mostly coconut oil betaine (cocamidopropyl betaine), obtained by chemical modification of coconut oil. Shampoos are usually classified based on their purpose, e.g. anti-dandruff, medicated, 2-in-1 shampoo, mild baby shampoo, basic beauty shampoo and premium conditioning shampoo (Butler, 2000). Zinc pyrithione (ZPT, bis[1-hydroxy-2 $(1 \mathrm{H})$-pyridinethionato-O,S] $(\mathrm{T}-4)$ zinc, Figure 1) that possesses a wide range of antifungal, antibacterial and anti-seborrheic properties is the most commonly used active ingredient in anti-dandruff shampoos (Marks et al., 1985; PiérardFranchimont et al., 2002a, 2002b; Reeder et al., 2011).

Zinc pyrithione is a complex of zinc and two molecules of organic bidentate ligand pyrithione (PT). ZPT is highly insoluble in water and is present in aqua-based products in the form of dispersion of fine solid particles, but it is soluble in $1 \mathrm{~mol}$<smiles>[O-][Te]12O[n+]3ccccc3[SH]1[n+]1ccccc1S2</smiles>

Fig. 1 Chemical structure of zinc pyrithione

$\mathrm{L}^{-1}$ hydrochloric acid or alkaline solution. Above $\mathrm{pH} 9.5$ value, zinc complex hydrolyzes to yield ionized pyrithione and zinc species (Paulus, 2005; Kromactive ZPT 48). Due to its high anti-fungal activity against fungus Malassezia (Pityrosporum ovale), the most common cause of dandruff, ZPT has been recognized in various studies as one of the most effective anti-dandruff ingredients (Babar et al., 1985; Gupta et al., 2014; Marks et al., 1985; Piérard-Franchimont et al., 2002a, 2002b; Reeder et al., 2011; Shuster, 1984) and therefore used extensively in antidandruff shampoos, conditioners, rinses, and hair dressings. ZPT is also a highly effective anti-fouling agent for the control of soft fouling marine organisms such as seaweed and bacterial and diatom slimes (Thomas, 1999).

The content of ZPT in anti-dandruff shampoos varies, subject both to the types and brand of commercial hair-care products (Colipa no. P81, 2014; Kromactive ZPT 48). The use of ZPT is authorized as a preservative in rinse-off cosmetic products, up to a maximum concentration of $0.5 \%$. For other uses, preferably as an anti-dandruff agent, ZPT is used in concentrations from $1 \%$ to $2 \%$ in appropriate cosmetic products (Colipa no. P81, 2014). Also, in accordance with Kromactive ZPT 48, ZPT in anti-dandruff shampoos is typically used at a level from $0.5 \%$ to $2 \%$ (Kromactive ZPT 48).

Environmental toxicity of pyrithione and metal salts on marine and freshwater organisms was previously assayed (Bao et al., 2008; Goka, 1999; Kobayashi and Okamura, 2002). Although acute and sub-chronic toxicities of ZPT from commercial formulations was found to be moderate to low, cosmetic products containing ZPT may affect aquatic environment (Goka,1999). Thus, a specific determination of ZPT is necessary for environmental risk assessment and the quality control of the commercial anti-dandruff preparations. 
Several analytical methods have been developed for ZPT determination, including titration with $\mathrm{Ti}^{3+}$ (Brooks and Sternglanz, 1959), thin layer chromatography (TLC) (De Kruijf et al., 1987), high performance liquid chromatography (HPLC) (Fenn and Alexander, 1988; Kondoh and Takano, 1987; Nakajima et al., 1990), high performance liquid chromatograph-mass spectrometry (HPLC-MS) (Thomas, 1999; Yamaguchi et al., 2006) and different electrochemical methods (Krivis et al., 1963; Pardo et al., 1996; Shih et al., 2004; Wang, 2000). The titrimetric methods are less attractive for practical analysis, owing to poor ZPT sensitivity and the presence of titratable interferents in hair care products. Quantitative TLC analysis necessitates the use of spectrodensitometry, being not very accurate and precise as well. Since $\mathrm{Zn}^{2+}$ interacts with certain reversed-phase packing materials or stainless steel components of the HPLC system, HPLC is not completely appropriate procedure for direct ZPT analysis (Wang, 2000). ZPT in commercial anti-dandruff shampoos was determined after pre-labeling with a fluorescent agent (Kondoh and Takano, 1987) or by trans-chelation to the $\mathrm{Cu}^{2+}$ complex using the normal-phase HPLC (Fenn and Alexander, 1988; Nakajima et al., 1990). Electrochemical oxidation of ZPT, using a glassy carbon electrode, carbon paste electrode, metal oxide modified carbon paste electrode and cobalt phthalocyanine modified screen-printed carbon electrode has been investigated in various alkaline solution by cyclic voltammetry, linear sweep voltammetry, chronoamperometry and differential pulse voltammetry (Shih et al., 2004; Wang, 2000). Even though the noted voltammetric methods are useful in sensitive and accurate analysis of real samples, the practical analysis requires extensive pretreatment of both sample and electrodes. The polarography was used for determination of mercapto and heavy metal-mercapto compounds such as 2-pyridinethiol, 2-pyridinethiol-1-oxide and 2-pyridinethiol-1-oxide metal salts in aquatic solutions (Krivis et al., 1963; Pardo et al., 1996). Polarography analysis is based mainly on electrochemical oxidation of anionic form of these compounds at the mercury electrode (Pardo et al., 1996).

The aim of this paper was to examine the applicability of differential pulse polarographic determination of zinc for simple assay of ZPT content in real samples such as anti-dandruff shampoos. DPP is based on the application of voltage pulses superimposed on a linearly rising base potential of working dropping mercury electrode (DME). The peak-shaped differential pulse (DP) polarogram represents the current difference, obtained by measuring the current, immediately before pulse application and another one just before the end of the pulse duration, as the function of linearly increasing potential (Bard and Faulkner, 2001). In order to determine the content of active ingredient and to evaluate the quality of commercial anti-dandruff shampoos, this study describes the applicability of DPP study of $\mathrm{Zn}^{2+}$ reduction to the indirect determination of ZPT. DPP method for determination of ZPT content is based on the two-electron reduction of $\mathrm{Zn}^{2+}$ formed by zinc pyrithione dissolving in ammoniacal buffer on DME, and the linear dependence of the reduction peak current vs. concentration of zinc. Ammoniacal buffer is commonly used as suitable supporting electrolyte for determination of zinc ions in different samples. (Dobos, 1980; Harvey, 2000; Riches, 1948; Warowna-Grzeskiewicz and Fijalek, 1998).

\subsection{Chemicals}

\section{MATERIAL AND METHODS}

The following chemicals were used for the determination of the zinc concentration and content of zinc-pyrithione in anti-dandruff shampoos: zinc chloride (Sigma Aldrich), 
hydrochloric acid (JT Baker), ammonium hydroxide (Merck), ammonium chloride (Merck) and Triton X-100 (Sigma Aldrich). All the chemicals were of analytical reagent grade. Branded commercial shampoo products with ZPT (marked as samples A, B and C) and without ZPT (marked as samples D and E) were purchased at local supermarkets. All analyzed shampoos contain almost same formulated matrix (basic formulation of shampoo), comprising a mixture of anionic surfactants, amphoteric surfactant and microcomponents. The ingredients were almost the same, except for D and E samples did not contain ZPT. Commercial cosmetics raw materials were used to probe the effect of the surface active ingredients, anionic surfactants $\mathrm{C}_{12}-\mathrm{C}_{13}$ SLES (Safol 23 E 2S, Sasol) and $\mathrm{C}_{12}-\mathrm{C}_{14}$ SLES (Cosmacol AES-70-2-24, Sasol) and amphoteric surfactant (coconut oil betaine) (Empigen BS / FA, Huntsman).

\subsection{Instruments}

Polarographic measurements were performed on a PAR 174A Polarographic analyzer (Princeton Applied Research Corp. USA) at room temperature $25.0^{\circ} \mathrm{C} \pm 1{ }^{\circ} \mathrm{C}$. A threeelectrode system, composed of a dropping mercury working electrode (DME), a saturated calomel reference electrode (SCE) and a platinum wire auxiliary electrode, was employed in polarographic cell volume of $20 \mathrm{~mL}$.

The optimized parameters for polarographic determination of zinc were: initial potential $0.7 \mathrm{~V}$; final potential $-1.7 \mathrm{~V}$; the amplitude of the voltage pulse $50 \mathrm{mV}$, pulse width $50 \mathrm{mV}$, time DME 1s and scan rate $10 \mathrm{mV} \mathrm{s}^{-1}$. Differential pulse (DP) polarograms were recorded on a Omnigraphic 2000.

\subsection{Procedures}

A stock solution of zinc chloride $\left(\mathrm{ZnCl}_{2}\right)$ concentration of $5.12 \times 10^{-3} \mathrm{~mol} \mathrm{~L}^{-1}$ was prepared by diluting $0.1024 \mathrm{~mol} \mathrm{~L}^{-1} \mathrm{ZnCl}_{2}$ solution of in deionized water $\left(18 \mathrm{M} \Omega \mathrm{cm}^{-1}\right.$, Milli Q, Millipore) in a ratio of 1: $20 \mathrm{v} / \mathrm{v}$. Ammoniacal buffer $\mathrm{pH} 10.2$ was used as supporting electrolyte, prepared by mixing $0.1 \mathrm{~mol} \mathrm{~L}^{-1} \mathrm{NH}_{3}$ and $0.2 \mathrm{~mol} \mathrm{~L}^{-1} \mathrm{NH}_{4} \mathrm{Cl}$ in the appropriate ratio and diluted in deionized water. The stock solutions of all analyzed anti-dandruff shampoos were obtained by dissolving $1 \mathrm{~mL}$ of shampoo in $50 \mathrm{~mL}$ of ammoniacal buffer, folowed by homogenization in ultrasonic bath (Iskra 300W) for 30 minutes. A stock solutions of anionic surfactants and amphoteric surfactant were prepared by dissolving of $1 \mathrm{~mL}$ of $10 \%$ solution in $50 \mathrm{~mL}$ deionized water and $1 \mathrm{~mL}$ of $1 \%$ solution in $50 \mathrm{~mL}$ deionized water, respectivly.

In order to eliminate the influence of dissolved oxygen, the buffer solution was deaerated for 5 minutes with high purity nitrogen (Messer, N2 5.0 min purity 99.999\%) in the electrolytic cell prior the addition of the sample. Base line of supporting electrolyte was recorded before each measurement. Then the $\mathrm{ZnCl}_{2}$ stock solution was injected into electrolytic cell with supporting electrolyte, the DPP curve was recorded in the potential range from -0.7 to $-1.7 \mathrm{~V}$ vs. SCE and the reduction DP peak current values were measured. The DPP current values of the supporting electrolyte and electroactive species were obtained under the same conditions, and the difference between both current values is taken as the analytical signal for determination of zinc and ZPT content in hair-care cosmetics samples. 


\section{RESULTS AND DISCUSSION}

\subsection{Determination of zinc and zinc pyrithione}

Determination of zinc pyrithione in commercial anti-dandruff shampoos using the DPP method is based on determination of zinc concentration, resulting from reduction of electroactive $\mathrm{Zn}^{2+}$ species at working DME. DP polarograms for standard zinc solutions obtained in ammoniacal buffer with added $40 \mu \mathrm{L}$ of $1 \%$ solution of Triton $\mathrm{X}-100$, by injection of different volumes $(50 \mu \mathrm{L}-600 \mu \mathrm{L}) 5.12 \times 10^{-3} \mathrm{~mol} \mathrm{~L}^{-1} \mathrm{ZnCl}_{2}$ stock solution. The obtained DP polarograms are shown in Figure 2A.

A non-ionic surfactant Triton $\mathrm{X}-100$ is widely used for a suppression of polarographic maxima, sharpens the peak and increases sensitivity. The DP peak height at the reducing potential $-1.33 \mathrm{~V}$ increases linearly with the concentration of zinc added. Quantification of zinc was achieved by using a calibration curve that was fitted by the least square method. The standard deviation of the response (SD) and slope of the calibration curve (S) was used to calculate the limit of detection (LOD) and limit of quantification (LOQ) by using the equation $\mathrm{LOD}=3.3(\mathrm{SD} / \mathrm{S})$ and $\mathrm{LOQ}=10(\mathrm{SD} / \mathrm{S})$, respectively. The calibration curve obtained by plotting the peak current vs. the concentration of zinc, presented in Figure 2B, show good linearity, ranging from $1.28 \times 10^{-5}$ to $1.39 \times 10^{-4} \mathrm{~mol} \mathrm{~L}^{-1}$. The obtained linear regression equation is $\mathrm{I}=-0.097+6.635 \times 10^{5} \mathrm{c}\left(\mathrm{R}^{2}=0.9986\right)$ and LOD and LOQ are $3.67 \times 10^{-6} \mathrm{~mol} \mathrm{~L}^{-}$ ${ }^{1}$ and $1.22 \times 10^{-5} \mathrm{~mol} \mathrm{~L}^{-1}$, respectively. Measurement uncertainty was determined on the basis of five measurements on $3.35 \times 10^{-5} \mathrm{~mol} \mathrm{~L}^{-1}$ solution - expressed as a relative standard deviation (RSD). The RSD for five consecutive recorded DP polarograms was $1.9 \%$.

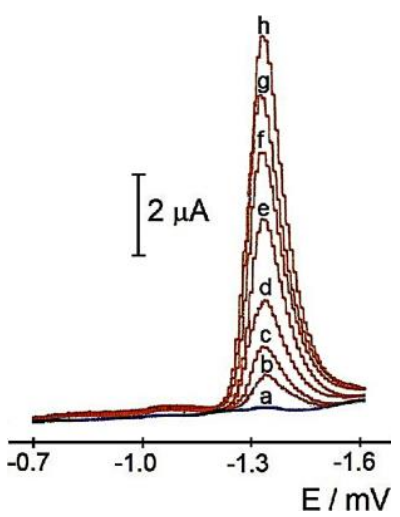

A)

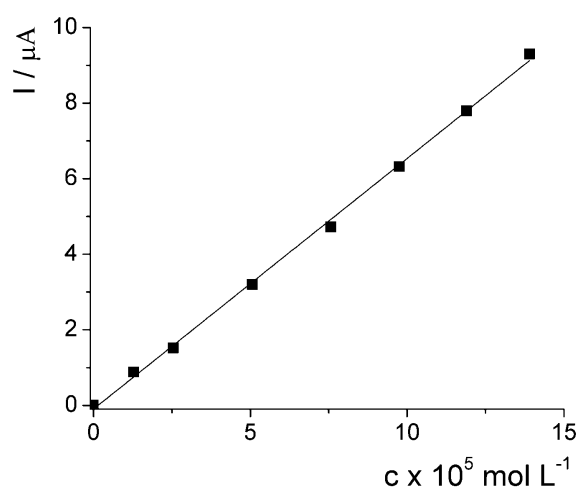

B)

Fig. 2 A) DP polarograms of zinc obtained in ammoniacal buffer $\mathrm{pH} 10.2$ with addition of $5.0 \times 10^{-4} \%$ Triton $\mathrm{X}-100$ for different concentrations of zinc: (a) supporting electrolyte, (b) $1.28 \times 10^{-5}$, (c) $2.55 \times 10^{-5}$, (d) $5.07 \times 10^{-5}$, (e) $7.57 \times 10^{-5}$, (f) $9.75 \times$ $10^{-5},(\mathrm{~g}) 1.19 \times 10^{-4}$ and (h) $1.39 \times 10^{-4} \mathrm{~mol} \mathrm{~L}^{-1}$. B) Corresponding calibration curve.

Optimised DPP for determination of zinc, was applied for determination of both the concentration of zinc and ZPT content in anti-dandruff shampoo samples A, B and C. Determination of zinc concentration was accomplished by standard addition method as 
shown in Figure 3. In the electrolytical cell with ammoniacal buffer $\mathrm{pH} 10.2$ and $0.5 \mathrm{~mL}$ of the diluted shampoo sample, three times equal volume $(50 \mu \mathrm{L}$ of sample $\mathrm{A}$ and $100 \mu \mathrm{L}$ of sample $\mathrm{B}$ and C) $5.12 \times 10^{-3} \mathrm{~mol} \mathrm{~L}^{-1} \mathrm{ZnCl}_{2}$ stock solution was added. The representative DP polarograms for sample $\mathrm{B}$ with three succesive standard additon of $\mathrm{ZnCl}_{2}$ stock solution and determinination of zinc concentration in the samples $\mathrm{A}$ and $\mathrm{B}$, are shown on Figures $3 \mathrm{~A}$ and $3 \mathrm{~B}$, respectively.

The values of zinc concentration and ZPT content in the analyzed shampoos samples A, B and $\mathrm{C}$ are shown in Table 1. The results show that ZPT values in samples B and $\mathrm{C}$ are within recommended value range of ZPT content $(1 \%-2 \%)$ in commercial anti-dandruff shampoos (Colipa no. P81, 2014). In contrast to samples B and C, which represent the products of the same brand, the content of ZPT in the sample A was considerably lower and below lower recommended value of $1 \%$. The obtained results of zinc concentration in the analyzed samples, were presented as a mean value \pm standard deviation (SD) in five determinations. As shown in Table 1, RSD values obtained from five replicate analyses of shampoos samples A, B and C ranging from $2.1 \%$ to $2.6 \%$, indicate excellent precision of the applied DPP method for determination of zinc and simple assay of ZPT content in commercial anti-dandruff shampoo.

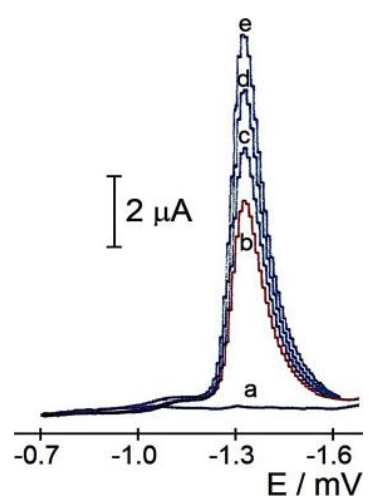

A)

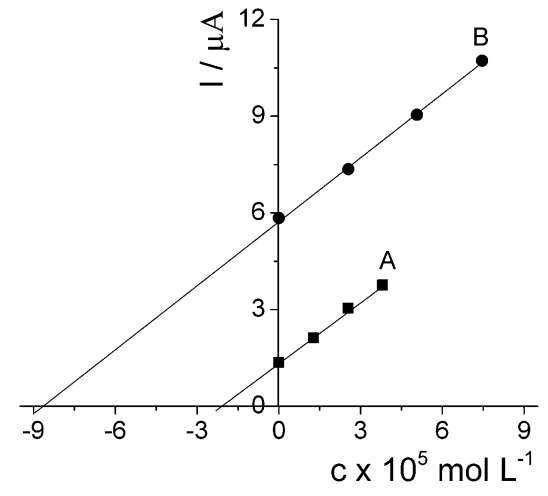

B)

Fig. 3 A) DP polarograms of zinc: (a) supporting electrolyte, (b) sample B, (c) - (e) additon of $100 \mu \mathrm{L} \mathrm{ZnCl}_{2}$ stock solution. B) Determination of the zinc concentration in the samples A and B by standard addition method.

Table 1 Results for the polarographic determination of zinc and zinc pyrithione in commercial anti-dandruff shampoos by standard addition method

\begin{tabular}{llllcc}
\hline $\begin{array}{l}\text { Sample } \\
\text { shampoo }\end{array}$ & $\begin{array}{l}\text { Linear regression } \\
\text { equation }\end{array}$ & $\begin{array}{l}\mathrm{c}_{\mathrm{Zn}} \pm \mathrm{SD}^{\mathrm{a}, \mathrm{b}} \\
\left(\mathrm{mol} \mathrm{L}^{-1}\right)\end{array}$ & $\begin{array}{l}\mathrm{c}_{\mathrm{Zn}}{ }^{\mathrm{c}} \\
\left(\mathrm{mol} \mathrm{L}^{-1}\right)\end{array}$ & $\begin{array}{r}\mathrm{c}_{\mathrm{ZPT}} \\
(\%)\end{array}$ & $\begin{array}{c}\mathrm{RSD} \\
(\%)\end{array}$ \\
\hline $\mathrm{A}$ & $\begin{array}{l}\mathrm{I}=1.347+6.409 \times 10^{5} \mathrm{c} \\
\mathrm{R}^{2}=0.9981\end{array}$ & $(2.102 \pm 0.044) \times 10^{-5}$ & $4.20 \times 10^{-2}$ & 0.28 & 2.1 \\
$\mathrm{~B}$ & $\begin{array}{l}\mathrm{I}=5.770+6.554 \times 10^{5} \mathrm{c} \\
\mathrm{R}\end{array}$ & $(8.804 \pm 0.229) \times 10^{-5}$ & $1.76 \times 10^{-1}$ & 1.15 & 2.6 \\
$\mathrm{C}$ & $\begin{array}{l}\mathrm{I}=0.9900 \\
\mathrm{R}^{2}=0.9971+6.659 \times 10^{5} \mathrm{c}\end{array}$ & $(9.111 \pm 0.210) \times 10^{-5}$ & $1.82 \times 10^{-1}$ & 1.19 & 2.3 \\
\hline
\end{tabular}

Abbreviations: ${ }^{\mathrm{a}}$ Number of determinations (n) $=5,{ }^{\mathrm{b}} \mathrm{SD}-$ standard deviation, ${ }^{\mathrm{c}} \mathrm{c}_{\mathrm{Zn}}$ in the sample shampoo 
Comparison of ZPT concentrations in the analyzed samples, with results obtained by significantly more demanding methods (from the analytical and time-consuming point of view), such as high performance liquid chromatography and voltammetric methods (Fenn and Alexander, 1988; Kondoh and Takano, 1987; Nakajima et al., 1990; Shih et al., 2004; Wang, 2000), shows a good concordance. The obtained values for A, B and C samples in the range $0.28 \%-1.19 \%$ are consistent with the values indicated in reference material $(0.23 \%-2.45 \%)$ for different unknown brand names of commercial anti-dandruff shampoos.

Recovery tests were carried out on anti-dandruff shampoos to evaluate the reproducibility and accuracy of the proposed DPP method for determination of ZPT. The recovery test was performed by adding the known amounts of zinc solutions in the shampoo samples A, B, E and D. Four cosmetic products were spiked with the amounts stated in Table 2.

Table 2 Recovery of zinc added to commercial shampoos

\begin{tabular}{lllll}
\hline $\begin{array}{l}\text { Sample } \\
\text { shampoo }\end{array}$ & Original value in the sample & \multicolumn{2}{c}{$\mathrm{c}_{\mathrm{Zn}}\left(\mathrm{mol} \mathrm{L}{ }^{-1}\right)$} & $\mathrm{RV}$ \\
& Added & Found $\pm \mathrm{SD}^{\mathrm{c}, \mathrm{d}}$ & $(\%)$ \\
\hline $\mathrm{A}^{\mathrm{a}}$ & $4.20 \times 10^{-2}$ & $2.56 \times 10^{-2}$ & $(6.72 \pm 0.14) \times 10^{-2}$ & 99.4 \\
$\mathrm{~B}^{\mathrm{a}}$ & $1.76 \times 10^{-1}$ & $5.12 \times 10^{-2}$ & $(2.24 \pm 0.05) \times 10^{-1}$ & 98.7 \\
$\mathrm{D}^{\mathrm{b}}$ & 0 & $5.12 \times 10^{-2}$ & $(5.08 \pm 0.11) \times 10^{-2}$ & 99.2 \\
$\mathrm{E}^{\mathrm{b}}$ & 0 & $5.12 \times 10^{-2}$ & $(5.15 \pm 0.11) \times 10^{-2}$ & 100.6 \\
\hline
\end{tabular}

Abbreviations: ${ }^{a}$ Shampoo samples with ZPT, ${ }^{b}$ Basic formulated shampoo samples without ZPT); ${ }^{\mathrm{c}}$ Number of determinations $(\mathrm{n})=5,{ }^{\mathrm{d}} \mathrm{SD}-$ standard deviation

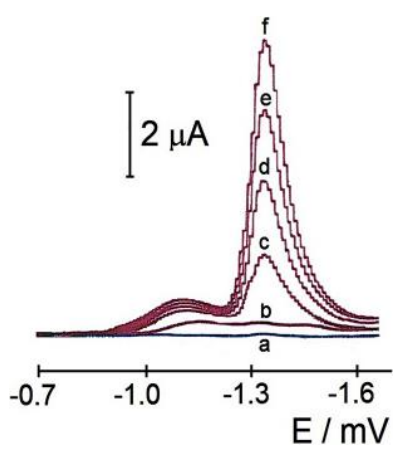

A)

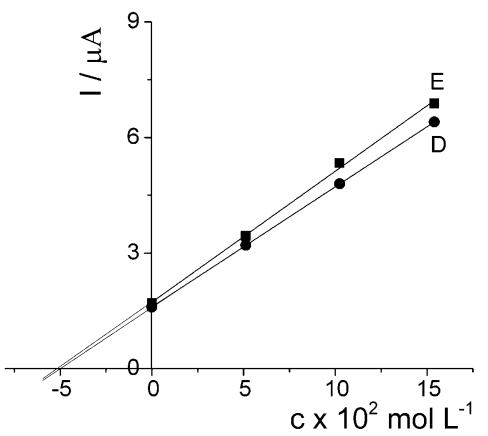

B)

Fig. 4 A) DP polarograms of zinc: (a) supporting electrolyte, (b) sample E, (c) spiked sample E, (d) - (f) additon of $100 \mu \mathrm{L} \mathrm{ZnCl}_{2}$ stock solution. B) Determination of zinc concentration in spiked samples $\mathrm{D}$ and $\mathrm{E}$ by standard addition method.

Figure 4A shows DP polarogams of sample E (in the absence of zinc), spiked sample $\mathrm{E}$ and three gradual additions of $\mathrm{ZnCl}_{2}$ standard solution in the volume of $100 \mu \mathrm{L}$. Determination of zinc concentration in the samples D and E by standard addition method is shown in Figure 4B. As shown in Table 2, there were observed excellent recoveries (ranging from $98.7 \%$ to $100.6 \%$ ). RSD values were below $2.2 \%$ in all cases. 


\subsection{The effect of the surface active ingredients}

In commercially formulated anti-dandruff shampoos an approximate amount of surface active ingredients is $11 \%$, of which $10 \%$ is anionic surfactants and $1 \%$ is amphoteric surfactant. The sum of all other components (active ingredients and micro-components) amounts to $2-3 \%$. For that reason, interference of surface active ingredients (ingredients with the highest amount) on the determination of zinc was assessed. The second reason for possible interference lies in the fact that surface active ingredients, as substances that can adsorb on the DME surface, may impact peak characteristics.

The matrix effects from surface active ingredients on the polarographic determination of zinc concentration was investigated in ammoniacal buffer with addition of $0.5 \mathrm{~mL}$ of anionic surfactant stock solution $\left(\mathrm{C}_{12}-\mathrm{C}_{13}\right.$ SLES or $\mathrm{C}_{12}-\mathrm{C}_{14}$ SLES) and amphoteric surfactant stock solution (coconut oil betaine) or $1.0 \mathrm{~mL}$ diluted samples $\mathrm{D}$ and $\mathrm{E}$ which do not contain ZPT (basic formulated matrix with all surface active ingredients and microcomponents). The concentration of the mentoined surfactants corresponds to their concentration in the diluted analyzed samples A, B and C. DP polarograms for standard zinc solutions in the presence of different anionic and amphoteric surfactants and samples $\mathrm{D}$ and $\mathrm{E}$, obtained by the same experimental procedure as well as in the presence of a previously used polarographic maximum suppresser-nonionic surfactant Triton X-100. Figure 5 shows the calibration plots obtained in the presence of various surfactants or samples E and D. Comparing the slope values obtained in the presence of surface active ingredients or whole formulated matrix, it has been found that the sensitivity does not differ more than $4.0 \%$. Since addition of surface active ingredients has not caused any change in peak characteristics of DP polarograms, it can be preliminary concluded that DPP method is suitable for the determination of zinc concentration.

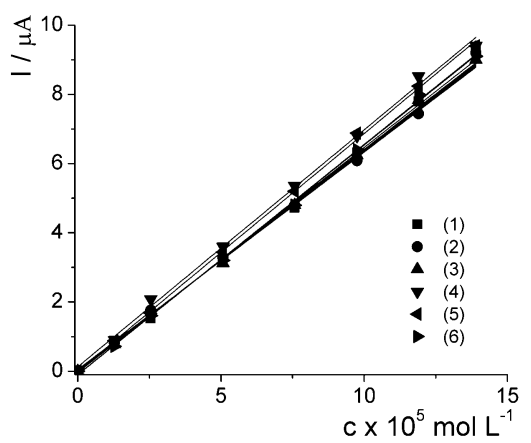

Fig. 5 Calibration curves of zinc obtained in ammoniacal buffer $\mathrm{pH} 10.2$ with addition of various surfactants and samples without ZPT: (1) $5.0 \times 10^{-4} \%$ Triton $\mathrm{X}-100$, (2) $5.0 \times 10^{-3} \% \mathrm{C}_{12}-\mathrm{C}_{13}$ SLES, (3) $5.0 \times 10^{-3} \% \mathrm{C}_{12}-\mathrm{C}_{14}$ SLES (4) $5.0 \times 10^{-4} \%$ coconut oil betaine, (5) sample D and (6) sample E.

The interference effects were also investigated by addition of known amounts of zinc solutions in the mixture of ammoniacal buffer and various surface active ingredients or samples D and E. As shown in Table 2 and Table 3, surface active ingredients and basic formulation of shampoo do not affect the determination of the zinc concentration in commercial anti-dandruff shampoos. In all cases the RSD values obtained from five replicate analyses were below $2.9 \%$. 
Table 3 Effect of surface active ingredients on zinc determination

\begin{tabular}{llll}
\hline $\begin{array}{l}\text { Concentrations of surface active } \\
\text { ingredient }(\%)\end{array}$ & Added & $\begin{array}{l}\mathrm{c}_{\text {Zn }}(\mathrm{mol} \mathrm{L} \\
\left.\text { Found }^{-1}\right)\end{array} \mathrm{SD}^{\mathrm{a}, \mathrm{b}}$ & $\mathrm{RV}(\%)^{\mathrm{a}}$ \\
\hline $5.0 \times 10^{-4}$ Triton X-100 & $5.12 \times 10^{-2}$ & $(5.14 \pm 0.14) \times 10^{-2}$ & 100.3 \\
$5.0 \times 10^{-3} \mathrm{C}_{12}-\mathrm{C}_{13}$ SLES & $5.12 \times 10^{-2}$ & $(5.06 \pm 0.12) \times 10^{-2}$ & 98.8 \\
$5.0 \times 10^{-3} \mathrm{C}_{12}-\mathrm{C}_{14}$ SLES & $5.12 \times 10^{-2}$ & $(5.16 \pm 0.15) \times 10^{-2}$ & 101.2 \\
$5.0 \times 10^{-4}$ Coconut oil betaine & $5.12 \times 10^{-2}$ & $(5.08 \pm 0.11) \times 10^{-2}$ & 99.2 \\
\hline
\end{tabular}

Abbreviations: ${ }^{\mathrm{a}}$ Number of determinations $(\mathrm{n})=5,{ }^{\mathrm{b}} \mathrm{SD}-$ standard deviation

The obtained results indicated that there is no polarographic interference of the matrix effects from surface active ingredients in the commercial anti-dandruff shampoos, and that the applied DPP method is applicable for determination of zinc concentration and indirectly for determination of ZPT content in real samples such as anti-dandruff shampoos.

\section{CONCLUSION}

This study describes DPP examination of $\mathrm{Zn}^{2+}$ reduction applicability from ammoniacal buffer $\mathrm{pH} 10.2$ to the ZPT determination in commercial anti-dandruff shampoos. The surface active ingredients and micro-components in the anti-dandruff shampoo did not show polarographic interference in the determination of zinc and do not affect the determination of the content of active ingredient ZPT. The ZPT content in two selected anti-dandruff shampoos range below maximum recommended value of ZPT in commercial hair-care products, but the content of ZPT in one of the studied samples is considerably lower and below the lowest recommended value. The approach allows for the analysis of real ZPT sample without any long-time sample pre-treatment procedures which are necessary in majority of other conventional methods.

The results obtained in this study indicate that simple, sensitive, accurate, precise, inexpensive and easy to operate DP polarographic method is suitable for a routine and rapid ZPT analysis and quality control of anti-dandruff shampoos.

\section{REFERENCES}

Babar, A., Kawilarang, C., Cutie, A.J., Plakogiannis, F.M., 1985. Drug Dev. Ind. Pharm., 11(8), 1507-1522. doi:10.3109/03639048509057683

Bao, V.W.W., Leung, K.M.Y., Kwok, K.W.H., Zhang, A.Q., Lui, G.C.S., 2008. Mar. Pollut. Bull., 57, 616-623. doi:10.1016/j.marpolbul.2008.03.041

Bard, A., Faulkner, L., 2001. Electrohemical methods, fundamental and application, $2^{\text {nd }}$ edition, Yohn Willey and soons, New York, pp. 286-290.

Brooks, R.T., Sternglanz, P.D., 1959. Anal. Chem., 31(4), 561-565. doi:10.1021/ac50164a031

Butler, H., 2000. Poucher's Perfumes, Cosmetics and Soaps, $10^{\text {th }}$ ed., Kluwer Academic Publishers, Dordrecht, pp. 289-306.

Colipa no. P81, 2014. The Scientific committee on cosmetic products and non-food products intended for consumers (SCCNFP). Draft evaluation and opinion on: zinc-pyrithione http://ec.europa.eu/health/ $\mathrm{ph}$ risk/ committees/sccp/documents/out225

De Kruijf, N., Rijk, M.A.H., Pranoto-Soetardhi, L.A., Schouten, A., 1987. J. Chromatogr. A, 410, 395-411. doi:10.1016/S0021-9673(00)90069-4

Dobos, D., 1980. Electrochemical Data (in Russian), Akademiai Kiado, Budapest, p. 281.

Fenn, R.J., Alexander, M.T., 1988. J. Liq. Chromatogr., 11(6), 3403-3413. doi:10.1080/01483918808082263 
Goka, K., 1999. Environ. Res. A, 81, 81-83. doi:10.1006/enrs.1998.3944

Gupta, M., Mahajan, V.K., Mehta, K.S., Chauhan, P.S., 2014. Dermatol. Res. Pract., 2014, 1-11. doi.org: $10.1155 / 2014 / 709152$

Harvey, D., 2000. Modern Analytical Chemistry, McGraw-Hill Higher Education, A Division of The McGraw-Hill Companies, p. 747.

Kobayashi, N., Okamura, H., 2002. Mar. Pollut. Bull., 44(8), 748-751. doi:10.1016/S0025-326X(02)00052-8

Kondoh, Y., Takano, S., 1987. J. Chromatogr., 408, 255-262. doi:10.1016/S0021-9673(01)81808-2

Krivis, A.F., Gazda, E.S., Supp, G.R., Robinson, M.A., 1963. Anal. Chem., 35(8), 966-968. doi: 10.1021/ac60201a013

Kromactive ZPT 48, Anti dandruf agent, Product Bulletin, Kromacare, Italia. http://www.kromacare.com/ public/13/TDS.

Marks, R. Pearse, A.D., Walker, A. P., 1985. Br. J. Dermatol., 112(4), 415-422. doi:10.1111/j.13652133.1985.tb02314.x

Nakaijima, K., Yasuda, T., Nakazawa, H., 1990. J. Chromatogr. A, 502, 379-384. doi:10.1016/S00219673(01)89602-3

Pardo, I., Angulo, M., Galvin, R.M., Rodriguez Mellado, J.M., 1996. Electrochim. Acta, 41(1), 133-139. doi:10.1016/0013-4686(95)00249-E

Paulus, W., 2005. Microbicides for the Protection of Materials: A Handbook, Kluwer Academic Publishers, Dordehct, p. 300.

Piérard-Franchimont, C., Goffin, V., Decroix, J Piérard, G. E., 2002. Skin. Pharmacol. Appl. Skin. Physiol., 15(6), 434-441. doi:10.1159/000066452

Piérard-Franchimont, C., Goffin, V., Henry, F., Uhoda, I., Braham, C., Piérard, G.E., 2002. Int. J. Cosmet. Sci., 24(5), 249-256. doi:10.1046/j.1467-2494.2002.00145.x

Reeder, N.L., Xu, J., Youngquist, R.S., Schwartz, J.R., Rust, R.C., Saunders, C.W., 2011. Br. J. Dermatol., 165(2), 9-12. doi:10.1111/j.1365-2133.2011.10571.x

Riches, J., 1948. New Phytol., 47(1), 1-16. doi:10.1111/j.1469-8137.1948.tb05089.x

Shih, Y., Zen, J. M., Kumar, A. S., Chen, P. Y., 2004. Talanta, 62, 912-917.doi:10.1016/i.talanta. 2003.10.039

Shuster, S., 1984. Br. J. Dermatol., 111(2), 235-242. doi:10.1111/i.1365-2133.1984.tb04050.x

Thomas, K.V., 1999. J. Chromatogr. A., 833(1), 105-109. doi:10.1016/S0021-9673(98)01009-7

Wang, L.H., 2000. Electroanalysis, 12，227-232. doi:10.1002/(SICI)1521-4109(200002)12:3<227: :AID-ELAN227>3.0.CO;2-I

Warowna-Grzeskiewicz, M., Fijalek, Z., 1998. Acta Pol. Pharm., 55(4), 263-266.

Yamaguchi, Y., Kumakura, A., Sugasawa, S., Harino, H., Yamada, Y., Shibata, K., Senda, T., 2006. Int. J. Environ. Anal. Chem., 86(1-2), 83-89. doi:10.1080/03067310500249930

\section{PRIMENA DP POLAROGRAFIJE ZA ODREĐIVANJE CINKA I SADRŽAJA CINK-PIRITIONA U ŠAMPONIMA PROTIV PERUTI}

Aktivni sastojak komercijalno formulisanih šampona protiv peruti je cink-pirition, koji ima antifungalno, antibakterijsko $i$ antiseboreično dejstvo. Određivanje cink-piritiona u šamponima protiv peruti primenom metode diferencijalne pulsne polarografije zasnivalo se na elektrohemijskoj redukciji jona cinka u amonijačnom puferu pH 10,2 i linearnoj zavisnosti intenziteta struje pika na redukcionom potencijalu - 1,33 V i koncentracije cinka. Metodom kalibracione krive je određen opseg linearnosti za određivanje koncentracije cinka od 1,28 $\times 10^{-5}$ do $1,39 \times 10^{-4}$ mol $L^{-1}$ i dobijena je linearna regresiona jednačina $I=-0,097+6,635 \times 10^{5} \mathrm{c}$. Utvrđeno je da površinski aktivne komponente u matriksu šampona ne pokazuju polarografsku interferenciju i ne utiču na određivanje koncentracije cinka i sadržaja cinkpiritiona u analiziranim šamponima. Koncentracije cinka u analiziranim uzorcima šampona određene su metodom standardnog dodatka i iznose 4,20 × $10^{-2} \mathrm{~mol} \mathrm{~L}^{-1}, 1,76 \times 10^{-1} \mathrm{~mol} \mathrm{~L}^{-1}$ i 1,82 $\times 10^{-1} \mathrm{~mol} \mathrm{~L}$. Rezultati polarografskog određivanja cinka i sadržaja cink-piritiona pokazuju da su dobijene vrednosti cink-piritiona $0,28 \%, 1,15 \%$ i 1,19\% ispod maksimalno preporučenog sadržaja cink-piritiona $u$ šamponima protiv peruti. Ova jednostavna i osetljiva metoda diferencijalno pulsne polarografije pogodna je za rutinsko i brzo određivanje sadržaja aktivnog sastojka i kontrolu kvaliteta šampona protiv peruti.

Ključne reči: Cink-pirition, šampon protiv peruti, diferencijalno pulsna polarografija 